\title{
Proizvodni troškovi ka॰ osnovni čimbenik konkurentnosti pilanske prerade četinjača
}

\section{Production Costs as a Basic Factor of Competitiveness of Softwood Sawmilling}

\author{
Izvorni znanstveni rad • Original scientific paper \\ Prispjelo-received: 3. 10. 2014. \\ Prihvaćeno-accepted: 6. 11. 2015. \\ UDK: $630 * 73 ; 674.032$ \\ doi:10.5552/drind.2015.1435
}

\begin{abstract}
SAŽETAK • Bogatstvo šuma na prostorima Republike Hrvatske uvjetovalo je razvoj pilanske prerade drva koja ima već stoljetnu tradiciju. S određenim zakašnjenjima u usporedbi s europskim zemljama, pilanska je prerada drva pratila razvoj tehnologije, zapošljavala stručnu radnu snagu te uz šumarstvo bila prva faza razvoja prerade drva. Troškovi su „u srcu“ mnogih poslovnih odluka. Nije dovoljno proučavati troškove za pojedino ili za ograničeno poslovno područje, već ih je nužno promatrati za cijeli lanac poslovnog procesa, tj. od dobavljača do kupca proizvoda ili usluga. Cilj ovog istraživanja bio je usporediti čimbenike u proizvodnji uz pomoć kojih se mogu uspoređivati proizvodnje domaćih i inozemnih poduzeća kako bi se dobila slika konkurentnosti pilanarstva u Republici Hrvatskoj. Čimbenici koji su se uspoređivali jesu trošak po jedinici proizvoda, trošak sirovine s prijevozom, trošak energije, trošak kapitala (u ovom primjeru amortizacije) te trošak radne snage. Radi dodatnog povećanja i održavanja konkurentnosti, potrebno je više ulagati u tehnologiju kako bi se smanjili troškovi po jedinici proizvoda. Također treba utvrditi optimalnu tehnologiju s obzirom na kvalitetu, kvantitetu i vrstu drva.
\end{abstract}

Ključne riječi: prerada drva, troškovi, konkurentnost, kalkulacije, trupci, piljena građa

\begin{abstract}
Abundance of forests in the territory of the Republic of Croatia was the reason for the development of sawmill industry that has a century long tradition. Although lagging behind the European countries, the Croatian sawmilling industry, along with forestry, represents the first phase of wood processing development, which is based on high manufacturing technology, trained employees and skilled workers. Costs are the core of many business decisions. It is, however, not enough to analyze the costs of a specific or restricted business area, but the costs of the entire business process - from supplier to product/service buyer. The aim of this paper was to compare the selected production process factors so as to make comparison between the Croatian and foreign companies, in order to get an idea of competitiveness of the Croatian sawmilling industry. Factors that were compared were: output cost per unit, costs of raw material including transportation, energy costs, cost of capital (in this case amortization), and the cost of labor. In order to further increase and maintain competitiveness of sawmill industry, it is necessary to make higher investments into technology with the aim to reduce the unit production costs. It is also necessary to determine the optimal technology in terms of quality, quantity and wood species.
\end{abstract}

Key words: wood processing, costs, competitiveness, calculations, logs, sawn wood

\footnotetext{
${ }^{1}$ Autorica je magistrica znanosti i direktorica Pilane Mrkopalj, Hrvatska. ${ }^{2}$ Autori su znanstvena novakinja i profesor Šumarskog fakulteta Sveučilišta u Zagrebu, Zagreb, Hrvatska.

Author is master of science and director of Sawmill Mrkopalj, Croatia. ${ }^{2}$ Authors are young researcher and professor at University of Zagreb, Faculty of Forestry, Zagreb, Hrvatska.
} 


\section{UVOD}

\section{INTRODUCTION}

Bogatstvo šuma na prostorima Republike Hrvatske uvjetovalo je razvoj pilanske prerade drva koja danas ima već stoljetnu tradiciju. U proteklom razdoblju, s određenim zakašnjenjima u odnosu prema europskim zemljama, taj je dio industrije pratio razvoj tehnologije, obučavao je i zapošljavao stručnu radnu snagu te uz šumarstvo bio prva faza razvoja prerade drva. Krajnji produkt pilana završavao je kao proizvod u građevinarstvu ili kao sirovina za daljnju preradu u drvnoj industriji. Troškovi su u „srcu“ mnogih poslovnih odluka. Tvrtke za preradu drva moraju stalno nastojati poboljšati ili barem zadržati svoj tržišni udio (Oblak i Glavonjić, 2014.). Postoji nekoliko načina da se to postigne (Oblak i Glavonjić, 2014.), npr. tvrtke moraju paziti na troškove jer svaka kuna više u trošku smanjuje profite poduzeća, odnosno poduzeće koje vodi brigu o profitu strogo će paziti na svoje troškove da bi održalo profitabilnost (Motik, 2004.). Za svaku poslovnu situaciju vrijedi pravilo da poduzeće mora biti dugoročni ponuđač s najnižim troškovima, da njegovi troškove moraju imati tendenciju snižavanja te imati potpunu sliku o troškovima i dobiti za svaki proizvod u svako vrijeme. Nije dovoljno proučavati troškove za pojedino ili za neko ograničeno poslovno područje, već ih treba pratiti u cijelom lancu poslovnog procesa, tj. od dobavljača do kupca proizvoda ili usluga. Na taj se način upravlja troškovima u cijelom poslovnom procesu (Figurić, 2003.).

Neprekidno traženje poboljšanja i težnja smanjenju troškova proces je koji se prema izvorniku naziva Kaizen (Figurić, 2003.). To je poslovno razmišljanje koje prati stalno snižavanje troškova i rast kvalitete. Bitan je timski rad menadžmenta, a i svih zaposlenika u traženju boljih rješenja kojima bi se mogao poboljšati proizvod ili usluga te racionalizirati poslovanje. Upravljanje troškovima neprekidna je aktivnost usporedbe troškova s tržištem i konkurencijom, jer poticaji za poboljšanje dolaze upravo od kupaca i konkurencije. Troškovima se mogu smatrati svi oni poslovni rashodi koji se mogu ukalkulirati u cijenu proizvoda odnosno u cijenu usluge (Santini, 2006.). Za troškove možemo ukratko reći da su novčano izrađena cijena utroška (Motik i Figurić, 1998.). Prema toj definiciji, ako je prikažemo putem proizvodnje, troškovi su količine potrošenih elemenata proizvodnje pomnožene njihovim cijenama. Na osnovi toga, ukupni se troškovi poduzeća mogu prikazati kao zbroj umnožaka količina i cijena svih utrošaka, odnosno ako je u proizvodnji potrošena određena količina materijala koja je nabavljena po određenoj nabavnoj cijeni, tada je trošak materijala umnožak količine proizvoda i nabavne cijene materijala utrošenoga u taj proizvod. Na taj način dobivamo i formulu koja će biti korištena u ovom radu, a u kojoj se navodi da količina rada pomnožena cijenom rada daje trošak rada, odnosno da su prosječni troškovi jednaki ukupnim troškovima podijeljenim s količinom proizvoda (Matić, 2000.). Cilj svakog poduzeća jest da uz što manje troškove ostvari što veću proizvodnju, odnosno da ostvari što veći profit (Škrtić, 2005.).
Potrebno je poznavati troškove da bismo mogli odrediti cijenu koštanja, a samim time i prodajnu cijenu proizvoda i vidjeti kako se ona ponaša s obzirom na konkurentske cijene na domaćemu i stranom tržištu (Škrtić, 1995.).

Cijene su egzogeni činitelji kada se promatraju s aspekta poslovne politike poduzeća. Cijene, dakle, pomažu proizvođačima da odrede koliko će sredstva alocirati na pojedine proizvodne faktore da bi ostvarili maksimalnu količinu proizvodnje (Babić, 2000.). Troškovi pripadaju unutrašnjim, a ostali vanjskim činiteljima politike cijena. Cijena je posljedica odnosa ponude i potražnje, ali i uzrok ponude i potražnje te ima svoje sastavne elemente. Odnos elemenata unutar cijene čini strukturu cijene. Pojedini elementi strukture cijene koštanja za proizvodno poduzeće jesu materijal izrade, amortizacija, troškovi rada, strane usluge, opći troškovi uprave i prodaje, dakle, troškovi proizvodnje (Gulin, 2003.). Jednako tako, na strukturu prodajne cijene utječu i korisnost nekog proizvoda, troškovi transporta, trgovine, kapitala, distribucije, a može postojati i utjecaj države putem poreza, carina, prireza i raznih taksi. Osnovni su činitelji politike poduzeća troškovi, potražnja, konkurencija, politika i društvene mjere.

Strukturu cijene određuje ponuda, mjesto ponude te potrebe i kupovna moć potrošača. Zato se razlikuju različite strukture cijena: cijena proizvodnje (cijena koštanja i prosječni profit), cijena ponude (iznos za koji je prodavatelj voljan prodati robu) i cijena potražnje ili nabavna cijena (iznos koji je voljan platiti kupac). Struktura cijene nije samo računski postupak izračunavanja udjela pojedinih elemenata u cijeni robe nego ona odražava tehnički odnos i odnos između rada i kapitala. Računski postupak utvrđivanja strukture cijena naziva se kalkulacijom. Metoda kalkulacije uvjetuje način izražavanja elemenata cijena. Za utvrđivanje cijena postojećih proizvoda primjenjuju se dvije skupine metoda: a) metode utvrđivanja cijena na temelju troškova (troškovno načelo) i b) metode utvrđivanja cijena na temelju ponude i potražnje (tržišno načelo).

\subsection{Metode utvrđivanja cijena na temelju troškova (troškovno načelo)}

1.1 Methods for determining prices based on costs (cost principle)

Određivanje cijena na temelju troškova obuhvaća sve troškove poduzeća uvećane za odgovarajuću dobit. Svako bi poduzeće trebalo obavljati određenu kontrolu svojih prodajnih cijena što znači: a) utvrditi osnovicu cijena za svoj proizvod; b) utvrditi različite cijene za različite modele; c) utvrditi različite cijene za različite uvjete prodaje s obzirom na količinu, područje itd.; d) utvrditi cijene za posebne narudžbe (specifikacije) ili posebne uvjete u kojima se poduzeće može naći (razne usluge piljenja).

Kada je riječ o troškovima kao podlozi za utvrđivanje cijena, nužno je analizirati troškove s obzirom na: 1. reagibilnost i remanenciju troškova - za velika poduzeća remanencija troškova ima veliko značenje zbog strukture njihovih ukupnih troškova. U kapitalno intenzivnim, velikim poduzećima, kao i u radno intenzivnima, fiksni troškovi imaju znatan udio 
u ukupnim troškovima. Odluku o smanjenju proizvodnje nije lako donijeti ako se ne želi smanjiti dobit i, eventualno, stvoriti gubitak. Bitno je utvrditi način ponašanja prosječnih ukupnih troškova, prosječnih varijabilnih troškova, prosječnih fiksnih troškova i graničnih troškova pri povećanju i smanjenju proizvodnje;

2. način ponašanja troškova proizvodnje i troškova prodaje s obzirom na količinu proizvodnje; obično se troškovi proizvodnje po jedinici proizvoda smanjuju ako proizvodnja raste, a troškovi prodaje rastu s povećanjem prodanih količina;

3. metode obračuna troškova materijala, amortizacije i dr.;

4. stupanj realnosti (stvarni, planski, standardni troškovi);

5. način izračunavanja troškova po jedinici proizvoda (direktni i indirektni ili posredni troškovi).

Cijene ovise o visini troškova proizvodnje i prodaje, a troškovi ovise o količini, kvaliteti i cijenama utrošenog materijala, primijenjenoj tehnologiji, utrošenoj energiji te raznim društvenim obvezama. Jednako tako, troškovi ovise i o metodi njihova obračuna.

\subsection{Metode utvrđivanja cijena na temelju ponude $i$ potražnje (tržišno načelo)}

1.2 Methods for determining prices based on supply and demand (market principle)

Cijena nije jednom zauvijek dana fiksna veličina. Ona ima svoju donju i gornju granicu. O manjem ili većem rasponu cijena ovisi i manja ili veća akumulativnost proizvoda. Gornja granica predstavlja potražnju, sredina ukupne troškove, a donja granica varijabilne troškove. Raspon cijena upućuje na zaključak da često nije ispravno promatrati cijene na temelju samo jednog kriterija (troška) već je potrebno uzeti u obzir više kriterija (troškove, potražnju, konkurenciju i sl.). U tržišnom su gospodarstvu ponuda i potražnja bitni činitelji politike cijena. Bitni činitelji tržišne politike cijena jesu veličina tržišta, tip tržišta, oblik tržišta, struktura tržišta, odnos ponude i potražnje, položaj proizvoda na tržištu, elastičnost ponude i potražnje s obzirom na cijene i dobit itd. U svom najjednostavnijem obliku metoda utvrđivanja cijena na temelju ponude i potražnje sastoji se u tome da se istraži opći sustav cijena u pojedinoj grani ili grupaciji te se na temelju toga određuju cijene vlastitih proizvoda. Kad se jednom tako utvrde cijene, troškovi se moraju držati u granicama definirane vrijednosti ako se želi ostvariti planirana dobit. Po pravilu, problemi se uvijek pojavljuju pri pronalaženju mogućih ušteda u troškovima. Bitno je, međutim, da postoji ravnoteža između potrebe za utvrđivanjem odgovarajućih cijena unutar uske mogućnosti konkurencijskih cijena i potrebe da se proizvede proizvod koji je konkurentan s obzirom na dizajn i kvalitetu.

Cilj ovog istraživanja bio je usporediti čimbenike u proizvodnji uz pomoć kojih se mogu uspoređivati proizvodnje domaćih i inozemnih poduzeća kako bi se dobila slika konkurentnosti pilanarstva u Republici Hrvatskoj. Uspoređivani su trošak po jedinici proizvoda; trošak sirovine s prijevozom; trošak energije, trošak kapitala (u ovom primjeru amortizacije) te trošak radne snage.
Jedna od pretpostavki jest da pilane u Republici Hrvatskoj svojom produktivnošću i troškovima ne mogu konkurirati na tržištu piljene građe u Europi te mogu proizvoditi samo za domaće tržište.

H1: Ako se ne poveća produktivnost pilanske prerade drva u Republici Hrvatskoj, onda pilane u našoj zemlji neće biti konkurentne na međunarodnom tržištu.

H2: Ako se smanje troškovi proizvodnje primarne prerade drva, tada će poduzeća koja se bave proizvodnjom piljene građe biti konkurentna na europskome i svjetskom tržištu.

\section{MATERIJALI I METODE \\ 2 MATERIAL AND METHODS}

Podaci o troškovima proizvodnje i podaci o samoj proizvodnji koji su radi istraživanja prikupljeni iz poduzeća A (u daljnjem tekstu: poligon A), poduzeća B (u daljnjem tekstu: poligon B) i poduzeća C (u daljnjem tekstu: poligon C) uvrštena su u dva modela obrade podataka kako bi se izračunao trošak po jedinici proizvoda. Da bi se dobio trošak po jedinici proizvoda, trebalo je razvrstati troškove prema vrsti i mjestu nastanka te prema proizvodnim jedinicama. Troškovi su dobiveni iz završnog računa na kraju godine. Za samo istraživanje, a kasnije i za usporedbu s drugim poligonima i državama bilo je potrebno utvrditi trošak sirovine bez prijevoza i s njim, iskorištenje, trošak energije, trošak amortizacije, trošak radne snage, troškove održavanja i ostale troškove kako bismo njihovim uvrštenjem u odgovarajuću formulu mogli izračunati trošak dobivene građe po jedinici proizvoda, u ovom primjeru trošak građe po $\mathrm{m}^{3}$.

Prikupljeni podaci, dobiveni dnevnim praćenjem proreza trupaca i izmjerom dobivene građe te izračunanim koeficijentom iskorištenja, uvršteni su u mjesečne tablice, a na kraju godine u ukupnu godišnju tablicu ispiljene sirovine. U godišnjoj tablici ispiljene sirovine prikazana je količina ispiljene sirovine prema vrstama drva, trošak sirovine, trošak prijevoza sirovine, iskorištenje prema vrstama drva i prema ukupnoj količini. Analiza podataka provedena je primjenom sljedećih dvaju modela.

I. Model obrade podataka. Dobivanje troška piljene građe po jedinici proizvoda u prvom primjeru za sva tri poligona počinje izradom tablice građe s podacima dobivenim iz proizvodnje $\mathrm{i}$ iskorištenja trupaca te izračunom dnevnog troška rada. Dnevni je trošak rada u tablici ukupnih troškova izračunan za pojedini poligon, a dobiven je tako da su zbrojeni pojedini godišnji troškovi radnih jedinica i podijeljeni brojem radnih dana u godini.

II. Model obrade podataka. Model zamišljenoga (fiktivnog) poduzeća sadržava izračun troška proizvodnje po jedinici za Njemačku i Austriju. Svjetsku konkurentnost pilanske prerade izložila je tvrtka Jaakko Pöyry 2004. godine. Postavljen je zamišljeni (fiktivni) model pilane koja preradi 600 $000 \mathrm{~m}^{3}$ trupaca u godini, i to $100 \%$ jele i smreke. Pretpostavljeno je da cijena i kvaliteta sirovine iznose $20 \%$ za podrazred 1B, $40 \%$ za podrazred 
Tablica 1. Analiza cijena pilanske prerade u ,zamišljenom“ poduzeću

Table 1 Price analysis of sawmill processing in 'model' company

\begin{tabular}{|c|c|c|}
\hline \multicolumn{3}{|c|}{$\begin{array}{l}\left.\text { Kalkulacija za } 600000 \text { m }^{3} \text { : pilana, dvije smjene, četinjače (u EUR/m } \mathbf{m}^{3}\right) \\
\text { Calculation }\left(600000 \mathrm{~m}^{3} \text {, sawmill, two shifts, coniferous (in EUR per m³) }\right.\end{array}$} \\
\hline & Njemačka / Germany & Austrija / Austria \\
\hline \multicolumn{3}{|c|}{ Trupci / Logs } \\
\hline Sirovina / Raw material & 63,4 & 65,8 \\
\hline Radnici / Employees & 9 & 6,5 \\
\hline Kapital/ Equity & 10,5 & 10,5 \\
\hline Ostalo / Other & 7,3 & 6,9 \\
\hline Ukupno / Total & 90,2 & 89,7 \\
\hline \multicolumn{3}{|c|}{ Piljena građa / Sawn wood } \\
\hline Sirovina / Raw material & 103,9 & 105,2 \\
\hline Radnici / Employees & 16,3 & 11,7 \\
\hline Kapital/Equity & 19,1 & 19,2 \\
\hline Ostalo / Other & 13,3 & 12,5 \\
\hline Ukupno /Total & 152,6 & 148,6 \\
\hline
\end{tabular}

Izvor: COST Action E44: A European wood processing strategy: Country reports, 2008

2A, $30 \%$ za podrazred $2 \mathrm{~B}$ i $10 \%$ za podrazred $3 \mathrm{AB}$, što odgovara našoj prosječnoj pilanskoj sirovini I. - III. klase (COST Action E44, 2008.). U prvom dijelu tablice 1 . cijena trupaca zbrojena je $\mathrm{s}$ cijenom prijevoza i za pojedinu zemlju uvrštena $u$ stavku SIROVINA. U tablicu su također uvršteni i podaci o kapitalu te ostali troškovi. U drugom dijelu tablice SIROVINA je dobivena na temelju iskorištenja pri piljenju trupaca i za Njemačku iznosi 61,5 \%, a za Austriju 62,5 \%. Zbrajanjem podataka iz drugog dijela tablice dobije se trošak proizvodnje po jedinici proizvoda za proizvodnju iz svake od tih zemalja. Trendovi cijena trupaca i piljenje građe prikazani su u tablici 2 .

\section{REZULTATI I RASPRAVA}

\section{RESULTS AND DISCUSSION}

\subsection{Odnos troškova promatranih poduzeća u} Republici Hrvatskoj (I. model)

3.1 Costs ratio between companies in the Republic of Croatia (Model I)

Prema podacima iz tablice 3., najskuplja sirovina u 2011. i 2010. godini bila je u poligonu A, i to u 2010. oko 9 \% viša nego u ostala dva poligona, a u 2011. za oko 4,5 \% viša nego u preostala dva poligona. Nasuprot tome, u poligonu A trošak drvne sirovine za 2009. godinu bio je oko $12 \%$ niži, odnosno oko $8 \%$ niži u
2008. nego u poligonima B i C. Razlika u cijeni sirovine bitno utječe na trošak građe po jedinici proizvoda jer, osim što je trošak veći za $10 \%$, iz tablice udjela troškova proizvodnje vidi se da je trošak sirovine trošak s najvećim udjelom u ukupnim troškovima istraživanih poligona. Troškovi rada vrlo često čine velik udio u troškovima proizvodnje te u odnosu prema ostalim troškovima dobivaju sve veće značenje (Polimeni i dr., 1999.). Drugi trošak s najvećim udjelom jest trošak radnika. Troškovi radnika najveći su u poligonu $\mathrm{C}, \mathrm{i}$ to $37 \%$ veći nego u druga dva poligona. Iz toga možemo zaključiti da su plaće radnika veće nego u druga dva istraživana poligona ili je broj radnika veći u poligonu C pa je stoga potrebno izdvojiti i veću količinu novca za plaće radnika. U ovom radu trošak kapitala jest trošak amortizacije. Amortizacija je svojevrsni dugoročni izvor financiranja poslovanja i ekspanzije poduzeća te je postupna transformacija dugoročno imobilizirane imovine u novčani oblik. Sama transformacija imovine iz jednog oblika u drugi ne mijenja strukturu kapitala poduzeća. Trošak kapitala od amortizacije ukupan je trošak kapitala (Orsag, 2002.). Troškovi kapitala podjednaki su u poligonima $\mathrm{A}$ i $\mathrm{B}$, dok su u poligonu $\mathrm{C}$ znatno niži, i to zato što je $\mathrm{u}$ poligonu $\mathrm{C}$ amortizacija obračunana po najnižoj obračunskoj stopi od 2,5\%.

Troškovi energije također su podjednaki za sva tri istraživana poligona i ne utječu bitno na trošak građe, a troškovi energije u ukupnim troškovima sudjelu-

Tablica 2. Trendovi cijena jelovih trupaca (Abies alba Mill.) (I. - III. klasa) i jelove piljene građe u odabranim zemljama (u $\mathrm{EUR} / \mathrm{m}^{3}$ )

Table 2 Price trends of fir logs (Abies alba Mill.) (I. - III. Class) and fir sawn wood in selected countries (in EUR per $\mathrm{m}^{3}$ )

\begin{tabular}{|l|c|c|c|c|}
\hline & $\mathbf{2 0 0 8 .}$ & $\mathbf{2 0 0 7 .}$ & $\mathbf{2 0 0 6 .}$ & $\mathbf{2 0 0 5 .}$ \\
\hline \multicolumn{5}{|c|}{ Njemačka/ Gremany } \\
\hline Trupci / Logs & 80,0 & 78,0 & 65,0 & 63,4 \\
\hline Piljena građa / Sawn wood & 186,9 & 183,6 & 161,9 & 159,3 \\
\hline \multicolumn{4}{|c|}{ Austrija/ Austria } \\
\hline Trupci / Logs & 80,0 & 86,0 & 75,0 & 65,8 \\
\hline Piljena građa /Sawn wood & 181,1 & 191,1 & 172,8 & 157,5 \\
\hline
\end{tabular}

Izvor: COST Action E44: A European wood processing strategy: Country reports, 2008 
Tablica 3. Odnos troškova poligona A, B i C (u EUR $\left./ \mathrm{m}^{3}\right)$

Table 3 Costs ratio of polygons A, B, and C (in EUR per $\mathrm{m}^{3}$ )

\begin{tabular}{|c|c|c|c|c|c|}
\hline \multicolumn{6}{|l|}{ Poligon A / Polygon A } \\
\hline & $\begin{array}{l}\text { Obračunska jedinica } \\
\text { Currency unit }\end{array}$ & 2011. & 2010. & 2009. & 2008. \\
\hline Trošak piljene građe / Cost of sawn wood & EUR & 139 & 141 & 117 & 122 \\
\hline $\begin{array}{l}\text { Sirovina s prijevozom } \\
\text { Raw material (including transportation) }\end{array}$ & EUR & 66 & 60 & 51 & 51 \\
\hline Radnici / Employees & EUR & 14 & 14 & 13 & 15 \\
\hline Kapital / Equity & EUR & 4 & 4 & 3 & 5 \\
\hline Energija / Energy & EUR & 4 & 4 & 4 & 4 \\
\hline $\begin{array}{l}\text { Produktivnost po zaposleniku } \\
\text { Productivity per employee }\end{array}$ & $\begin{array}{l}\mathrm{m}^{3} / \text { radnici } \\
m^{3} \text { per employees }\end{array}$ & 725 & 744 & 767 & 685 \\
\hline \multicolumn{6}{|l|}{ Poligon B / Polygon B } \\
\hline & $\begin{array}{l}\text { Obračunska jedinica } \\
\text { Currency unit }\end{array}$ & 2011. & 2010. & 2009. & 2008. \\
\hline Trošak piljene građe / Cost of sawn wood & EUR & 135 & 138 & 135 & 131 \\
\hline $\begin{array}{l}\text { Sirovina s prijevozom } \\
\text { Raw material (including transportation) }\end{array}$ & EUR & 55 & 54 & 54 & 55 \\
\hline Radnici / Employees & EUR & 17 & 18 & 17 & 14 \\
\hline Kapital / Equity & EUR & 6 & 6 & 8 & 9 \\
\hline Energija / Energy & EUR & 5 & 4 & 4 & 3 \\
\hline $\begin{array}{l}\text { Produktivnost po zaposleniku } \\
\text { Productivity per employee }\end{array}$ & $\begin{array}{l}\mathrm{m}^{3} / \mathrm{radnici} \\
m^{3} \text { per employees }\end{array}$ & 713 & 706 & 712 & 723 \\
\hline \multicolumn{6}{|l|}{ Poligon C / Polygon C } \\
\hline & $\begin{array}{l}\text { Obračunska jedinica } \\
\text { Currency unit }\end{array}$ & 2011. & 2010. & 2009. & 2008. \\
\hline Trošak piljene građe / Cost of sawn wood & EUR & 132 & 118 & 129 & 109 \\
\hline $\begin{array}{l}\text { Sirovina s prijevozom } \\
\text { Raw material (including transportation) }\end{array}$ & EUR & 60 & 56 & 53 & 49 \\
\hline Radnici / Employees & EUR & 22 & 15 & 21 & 20 \\
\hline Kapital / Equity & EUR & 3 & 2 & 3 & 3 \\
\hline Energija / Energy & EUR & 4 & 3 & 4 & 4 \\
\hline $\begin{array}{l}\text { Produktivnost po zaposleniku } \\
\text { Productivity per employee }\end{array}$ & $\begin{array}{l}\mathrm{m}^{3} / \text { radnici } \\
m^{3} \text { per employees }\end{array}$ & 439 & 597 & 426 & 426 \\
\hline
\end{tabular}

je u prosjeku s $10 \%$. Nadalje, trošak građe prosječno je jednak za sva tri istraživana poligona, a na nj jedino bitno utječe svaka promjena troška sirovine te trošak radnika, koji i u ukupnim troškovima čine najveći udio.

Proizvodnost ili produktivnost općenito označava omjer proizvedenih dobara i potrebe za čimbenicima proizvodnje ili uspješnost pri obavljanju nekog posla s obzirom na upotrijebljene resurse (Bizjak, 1993.). Produktivnost po radniku podjednaka je za istraživane poligone A i B, dok je za poligon $\mathrm{C}$ u prosjeku niža za $40 \%$. Razlog tome je da prva dva poligona raspolažu modernijom tehnologijom pa im je potreban manji broj zaposlenih u proizvodnji, što nije točno jer sva tri istraživana poligona posjeduju jednako zastarjelu tehnologiju, ili da poligon $\mathrm{C}$ ne prerađuje dovoljno trupaca $\mathrm{s}$ obzirom na broj zaposlenih.

\subsection{Odnos troškova zamišljenog modela poduzeća i troškova istraživanih poligona $A$, B i C (II. model)}

3.2 Costs ratio between the model company and polygons $\mathrm{A}, \mathrm{B}$, and $\mathrm{C}$ (Model 2)

Prema tablicama 4. i 5. trošak sirovine je $20 \%$ veći u Njemačkoj i Austriji od troška sirovine u Repu- blici Hrvatskoj. Zbog udjela od $50 \%$ u ukupnim troškovima, trošak sirovine ima i najveći utjecaj na promjenu troška građe po jedinici proizvoda. Iz podataka se vidi da je odnos troškova radnika u hrvatskim poduzećima 20 - $30 \%$, a u Njemačkoj i Austriji iznosi 6,5 $-9 \%$ za trupce te $13-18 \%$ za piljenu građu.

Iz modela opisanog poduzeća (tabl. 5.) može se zaključiti da se u proizvodnom procesu primjenjuje novija tehnologija velikog kapaciteta piljenja koja ne zahtijeva velik broj radnika kao u hrvatskim poduzećima sa zastarjelom tehnologijom, što povećava troškove. Budući da je u hrvatskim poduzećima tehnologija zastarjela, i odnos troškova kapitala od $6 \%$ manji je od $10 \%$ ukupnih troškova Njemačke i Austrije, te kao trošak ne utječe bitno na povećanje troška građe, odnosno daje mogućnost konkurencije.

Jednako je tako utvrđeno da su ostali troškovi za $50-60 \%$ manji u odnosu prema ostalim troškovima u poligonima A, B i C. S obzirom na to koji troškovi u ovom primjeru čine ostale troškove (troškovi održavanja, troškovi energije...), jedan od zaključaka može biti da zbog zastarjele tehnologije rastu troškovi održavanja i kupnje rezervnih dijelova. 
Tablica 4. Usporedba troškova prema modelu ,zamišljenog“ poduzeća za poligone A, B i C (u EUR/m³)

Table 4 Comparison of costs according to the model company for polygons A, B, and C (in EUR per $\mathrm{m}^{3}$ )

\begin{tabular}{|c|c|c|c|c|}
\hline \multicolumn{5}{|c|}{$\begin{array}{l}\left.\text { Kalkulacija za } 22 \mathbf{0 0 0} \mathbf{~ m}^{3} \text { : pilana, dvije smjene, četinjače (u EUR/m³ }\right) \\
\text { Calculation } 22000 \mathrm{~m}^{3} \text {, sawmill, two shifts, coniferous (in EUR per m³) }\end{array}$} \\
\hline Poligon A / Polygon $A$ & 2011. & 2010. & 2009. & 2008. \\
\hline \multicolumn{5}{|l|}{ Trupci / Logs } \\
\hline Sirovina / Raw material & 66,1 & 59,0 & 50,9 & 50,9 \\
\hline Radnici / Employees & 21,2 & 14,2 & 13,1 & 14,9 \\
\hline Kapital/ Equity & 5,1 & 3,6 & 13,1 & 14,9 \\
\hline Ostalo / Other & 11,1 & 8,1 & 9,3 & 9,8 \\
\hline Ukupno / Total & 103,5 & 85,0 & 76,3 & 80,3 \\
\hline \multicolumn{5}{|l|}{ Piljena građa / Sawn wood } \\
\hline Sirovina / Raw material & 94,4 & 84,3 & 72,6 & 72,7 \\
\hline Radnici / Employees & 35,3 & 23,7 & 21,9 & 24,9 \\
\hline Kapital/ Equity & 8,5 & 6,1 & 5,1 & 7,9 \\
\hline Ostalo / Other & 18,4 & 13,5 & 15,5 & 16,3 \\
\hline Ukupno /Total & 156,7 & 127,6 & 115,1 & 121,7 \\
\hline \multicolumn{5}{|c|}{$\begin{array}{l}\text { Kalkulacija za } 60000 \text { m }^{3} \text { : pilana, dvije smjene, četinjače }(\mathbf{u} \text { EUR/m } \\
\left.\text { Calculation } 60000 \mathrm{~m}^{3} \text {, sawmill, two shifts, coniferous (in EUR per m}{ }^{3}\right)\end{array}$} \\
\hline Poligon B / Polygon B & 2011. & 2010. & 2009. & 2008. \\
\hline \multicolumn{5}{|l|}{ Trupci / Logs } \\
\hline Sirovina / Raw material & 55,3 & 53,3 & 54,4 & 55,1 \\
\hline Radnici / Employees & 17,1 & 18,4 & 17,2 & 14,3 \\
\hline Kapital/ Equity & 6,0 & 6,1 & 7,5 & 8,8 \\
\hline Ostalo / Other & 13,0 & 16,1 & 13,4 & 11,8 \\
\hline Ukupno / Total & 91,5 & 93,9 & 92,5 & 90,0 \\
\hline \multicolumn{5}{|l|}{ Piljena građa / Sawn wood } \\
\hline Sirovina / Raw material & 85,1 & 82,0 & 83,7 & 84,7 \\
\hline Radnici / Employees & 28,6 & 30,7 & 28,7 & 23,9 \\
\hline Kapital/Equity & 10,0 & 10,1 & 12,4 & 14,7 \\
\hline Ostalo / Other & 21,7 & 26,8 & 22,3 & 19,6 \\
\hline Ukupno / Total & 145,4 & 149,6 & 147,1 & 142,9 \\
\hline \multicolumn{5}{|c|}{$\begin{array}{l}\left.\text { Kalkulacija za } 22000 \text { m}^{3} \text { : pilana, dvije smjene, četinjače (u EUR/m³ }\right) \\
\text { Calculation } 22000 \mathrm{~m}^{3} \text {, sawmill, two shifts, coniferous (in EUR per m }{ }^{3} \text { ) }\end{array}$} \\
\hline Poligon C / Polygon C & 2011. & 2010. & 2009. & 2008. \\
\hline \multicolumn{5}{|l|}{ Trupci / Logs } \\
\hline Sirovina / Raw material & 59,9 & 56,2 & 53,4 & 48,8 \\
\hline Radnici / Employees & 21,6 & 15,0 & 21,0 & 19,6 \\
\hline Kapital/ Equity & 2,5 & 1,8 & 2,5 & 2,5 \\
\hline Ostalo / Other & 10,6 & 6,9 & 8,5 & 9,5 \\
\hline Ukupno / Total & 94,6 & 79,9 & 85,4 & 80,4 \\
\hline \multicolumn{5}{|l|}{ Piljena građa / Sawn wood } \\
\hline Sirovina / Raw material & 92,2 & 86,4 & 82,1 & 75,0 \\
\hline Radnici / Employees & 36,0 & 25,0 & 35,0 & 32,7 \\
\hline Kapital/ Equity & 4,1 & 3,0 & 4,2 & 4,2 \\
\hline Ostalo / Other & 17,7 & 11,5 & 14,2 & 15,8 \\
\hline Ukupno /Total & 150,1 & 125,9 & 135,5 & 127,6 \\
\hline
\end{tabular}

\section{ZAKLJUČCI}

\section{CONCLUSIONS}

Na osnovi istraživanja odnosa troškova zamišljenog poduzeća u promatranim zemljama Europe i stvarnih troškova u promatranim hrvatskim pilanama, može se istaknuti sljedeće.

1. Cijena sirovine u promatranom je razdoblju u europskim zemljama bila viša nego u Hrvatskoj. Za točnu usporedbu trebalo bi provesti i analizu kvantitativnog iskorištenja trupaca jednakih klasa jer standardi razvrstavanja trupaca nisu iden- tični. U Hrvatskoj se trupci razvrstavaju na I., II. i III. klasu, a u Europi na A, B, C i D.

2. Struktura dobivene sirovine u Austriji i Njemačkoj bitno je drugačija, što uvjetuje i primjenu različitih tehnologija piljenja trupaca. U navedenim su zemljama dobiveni trupci manjeg promjera i ujednačene kvalitete, pa se mogu piliti na jarmačama, tračnim pilama trupčarama u paru ili na linijama kružnih pila uz mogućnost velike automatizacije i produktivnosti. U Hrvatskoj trupci imaju velik raspon promjera, a velike su i razlike u kvaliteti, pa je radi pravilnoga kvalitativnog i kvantitativnog 
Tablica 5. Usporedba troškova prema modelu ,zamišljenog“ poduzeća za Njemačku i Austriju (u EUR/m³)

Table 5 Comparison of costs according to the model company for Germany and Austria (in EUR per $\mathrm{m}^{3}$ )

\begin{tabular}{|c|c|c|c|c|}
\hline \multicolumn{5}{|c|}{$\begin{array}{l}\text { Kalkulacija za } 600000 \mathbf{~ m}^{3} \text { : pilana, dvije smjene, četinjače (u EUR/ m³) } \\
\text { Calculation }\left(600000 \mathrm{~m}^{3} \text {, sawmill, two shifts, coniferous (in EU per m }{ }^{3}\right)\end{array}$} \\
\hline Njemačka / Germany & 2011. & 2010. & 2009. & 2008. \\
\hline \multicolumn{5}{|l|}{ Trupci / Logs } \\
\hline Sirovina / Raw material & 80,0 & 78,0 & 65,0 & 63,4 \\
\hline Radnici / Employees & 9 & 9 & 9 & 9 \\
\hline Kapital/Equity & 10,5 & 10,5 & 10,5 & 10,5 \\
\hline Ostalo / Other & 7,3 & 7,3 & 7,3 & 7,3 \\
\hline Ukupno / Total & 103,5 & 85,0 & 76,3 & 90,2 \\
\hline \multicolumn{5}{|l|}{ Piljena građa / Sawn wood } \\
\hline Sirovina / Raw material & 133,3 & 130,0 & 108,3 & 105,7 \\
\hline Radnici / Employees & 18,0 & 18,0 & 18,0 & 18,0 \\
\hline Kapital/Equity & 21,0 & 21,0 & 21,0 & 21,0 \\
\hline Ostalo / Other & 14,6 & 14,6 & 14,6 & 14,6 \\
\hline Ukupno /Total & 186,9 & 183,6 & 161,9 & 159,3 \\
\hline \multicolumn{5}{|c|}{$\begin{array}{l}\text { Kalkulacija za } 600000 \mathbf{~ m}^{3} \text {, pilana, dvije smjene, četinjače (u EUR/m }{ }^{3} \text { ) } \\
\text { Calculation } 600000 \mathrm{~m}^{3} \text {, sawmill, two shifts, coniferous (in EUR per m }{ }^{3} \text { ) }\end{array}$} \\
\hline Austrija / Austria & 2011. & 2010. & 2009. & 2008. \\
\hline \multicolumn{5}{|l|}{ Trupci / Logs } \\
\hline Sirovina / Raw material & 80,0 & 86,0 & 75,0 & 65,8 \\
\hline Radnici / Employees & 6,5 & 6,5 & 6,5 & 6,5 \\
\hline Kapital/Equity & 10,5 & 10,5 & 10,5 & 10,5 \\
\hline Ostalo / Other & 6,9 & 6,9 & 6,9 & 6,9 \\
\hline Ukupno / Total & 103,9 & 109,9 & 98,9 & 89,7 \\
\hline \multicolumn{5}{|l|}{ Piljena građa / Sawn wood } \\
\hline Sirovina / Raw material & 133,3 & 143,3 & 125,0 & 109,7 \\
\hline Radnici / Employees & 13,0 & 13,0 & 13,0 & 13,0 \\
\hline Kapital/Equity & 21,0 & 21,0 & 21,0 & 21,0 \\
\hline Ostalo / Other & 13,8 & 13,8 & 13,8 & 13,8 \\
\hline Ukupno /Total & 181,1 & 191,1 & 172,8 & 157,8 \\
\hline
\end{tabular}

iskorištenja trupce nužno piliti na tračnim pilama trupčarama. Stoga je otežana primjena procesne tehnologije i automatizacije.

3. Iako su plaće zaposlenika u Republici Hrvatskoj niže nego u europskim zemljama, cijena rada po jedinici proizvoda zbog niske je produktivnosti viša nego u europskim zemljama. Prijeko je potrebno novim investicijama unaprijediti tehnologiju u našim pilanama i povećati produktivnost.

4. U europskim se zemljama u pilansku proizvodnju ulaže mnogo više kapitala nego u nas, pa je i trošak kapitala veći. Međutim, veća ulaganja rezultiraju boljom tehnološkom opremljenošću, a time i većom proizvodnjom po radniku, boljim uvjetima rada i većom sigurnošću na radu.

5. Analizom ukupnih troškova može se zaključiti da pilane u Gorskom kotaru mogu konkurirati europskim pilanama. Prednost su manji ukupni troškovi po $\mathrm{m}^{3}$ građe.

Radi dodatnog povećanja konkurentnosti i njezina održavanja, potrebno je više ulagati u tehnologiju kako bi se smanjili troškovi po jedinici proizvoda. Također treba utvrditi optimalnu tehnologiju s obzirom na kvalitetu, kvantitetu i vrstu drva. Ovim je radom istraženo koji čimbenici bitno utječu na trošak piljene građe, te su time dane smjernice za buduća istraživa- nja, što bi u konačnici rezultiralo smanjenjem troškova poslovanja i povećanjem konkurentnosti poduzeća.

\section{LITERATURA}

\section{REFERENCES}

1. Babić, M., 2000: Mikroekonomska analiza, Mate, Zagreb.

2. Bizjak, F., 1993: Zbirka vaj za ekonomiko podjetja. Univerza v Ljubljani, Biotehniška fakulteta, Nova Gorica.

3. Figurić, M., 2003: Menadžment troškova u drvnotehnološkim procesima, Zagreb.

4. Gulin, D., 2003: Obračun troškova proizvodnje po radnom nalogu, RIF 11/2003. Zagreb.

5. Motik, D., 2004: Price calculation in multiphase production of wooden products, International science conference "Current questions and development tendencies in woodworking industry". Ohrid, Macedonia.

6. Motik, D.; Figurić, M., 1998: Calculation methods and their influence upon the business of a company. 1. Vedecká konferencia s medzinárodnou účast'ou nové trendy v systémoch riadenia podnikov, Herl'any.

7. Oblak, L.; Glavonjić, B., 2014: A Model for the Evaluation of Radio Advertisements for the sale of Timber Products. Drvna industrija, 65 (4): 303-308 http://dx.doi.org/10.5552/drind.2014.1357.

8. Orsag, S., 2002: Budžetiranje kapitala - Procjena investicijskih projekata. Masmedia, Zagreb. 
9. Polimeni, S.; Handy, A.; Cashin, A., 1999: Troškovno računovodstvo. Faber\&Zgombić Plus, Zagreb.

10. Santini, I., 2006: Troškovi u poslovnom odlučivanju. Hibis, d.o.o., Centar za ekonomski consalting, Zagreb.

11. Škrtić, M., 1995: Smanjenje troškova u funkciji povećanja konkurentnosti, RRIF, br. 7, opseg 1,1 a.a., Zagreb.

12. Škrtić, M., 2005: Upravljanje troškovima s ciljem povećanja konkurentnosti. Zbornik radova: Upravljanje troškovima - povećanje konkurentnosti i uspješnosti poslovanja; Zagreb - Zadar, M.A.K. - Golden.
13. ***COST Action E44: A European wood processing strategy: Country reports, 2008.

\section{Corresponding address:}

ANDREJA PIRC BARČIĆ, Ph.D.

University of Zagreb

Faculty of Forestry

Svetošimunska 25

10000 Zagreb, CROATIA

e-mail: apirc@sumfak.hr 